\title{
Eugenia neonitida Sobral and Eugenia rotundifolia Casar. (Myrtaceae) Essential Oils: Composition, Seasonality Influence, Antioxidant Activity and Leaf Histochemistry
}

\author{
Anna C. A. Defaveri, ${ }^{a, b}$ Alice Sato, ${ }^{*, a, b}$ Leandro B. Borré, ${ }^{c}$ Daniel L. M. Aguiar, ${ }^{c}$ \\ Rosane A. S. San Gil, ${ }^{c}$ Rosani C. O. Arruda ${ }^{d}$ and Carlos A. S. Riehl
}

${ }^{a}$ Centro de Ciências da Saúde, Universidade Federal do Rio de Janeiro, Av. Carlos Chagas Filho, 373, Bloco K, Cidade Universitária, Ilha do Fundão, 21941-590 Rio de Janeiro-RJ, Brazil

${ }^{b}$ Instituto de Biociências, Universidade Federal do Estado do Rio de Janeiro, Av. Pasteur 458, Urca, 22290-240 Rio de Janeiro-RJ, Brazil

'Instituto de Química, Universidade Federal do Rio de Janeiro, Av. Athos da Silveira Ramos, 149, Bloco A, Cidade Universitária, Ilha do Fundão, 21949-900 Rio de Janeiro-RJ, Brazil

${ }^{d}$ Centro de Ciências Biológicas e da Saúde, Universidade Federal de Mato Grosso do Sul, Av. Senador Felinto Müller s/n, Cidade Universitária, 79070-900 Campo Grande-MS, Brazil

Investigou-se a influência da sazonalidade na composição do óleo essencial de folhas frescas de Eugenia neonitida Sobral e Eugenia rotundifolia Casar. (Myrtaceae) coletadas trimestralmente, assim como a atividade antioxidante do óleo essencial de folhas secas e a histoquímica foliar. Os componentes majoritários do óleo essencial de E. neonitida foram biciclogermacreno, germacreno D e $\beta$-cariofileno e os de $E$. rotundifolia foram $\alpha$-pineno, $\beta$-pineno e $\beta$-cariofileno. Os óleos essenciais de ambas as espécies apresentaram principalmente hidrocarbonetos e álcoois cíclicos, sendo o óleo essencial de E. neonitida composto principalmente por sesquiterpenos e o de E. rotundifolia por monoterpenos. A precipitação parece influenciar na composição dos óleos essenciais de ambas as espécies. O óleo essencial de folhas secas apresentou baixa atividade antioxidante. Os testes histoquímicos evidenciaram que as cavidades secretoras armazenam soluções complexas e contêm, além dos óleos essenciais, outras classes de lipídeos.

The seasonality influence on the essential oil composition of trimestrially collected fresh leaves of Eugenia neonitida Sobral and Eugenia rotundifolia Casar. (Myrtaceae) was investigated, as well as the antioxidant activity of dried leaves essential oils, and the leaf histochemistry. Eugenia neonitida essential oil major compounds were bicyclogermacrene, germacrene D, and $\beta$-caryophyllene. Eugenia rotundifolia major compounds were $\alpha$-pinene, $\beta$-pinene, and $\beta$-caryophyllene. The essential oils of both species were mainly composed by cyclic hydrocarbons and alcohols; sesquiterpenes in E. neonitida and monoterpenes in E. rotundifolia. Precipitation appears to influence both species essential oils composition. Essential oils from dried leaves exhibited weak antioxidant activities. Both species have presented secretory cavities filled with a complex solution of essential oils and other lipid classes, according to histochemical tests.

Keywords: Eugenia neonitida, Eugenia rotundifolia, essential oil, antioxidant activity, histochemistry

\section{Introduction}

Eugenia neonitida Sobral and Eugenia rotundifolia Casar. (Myrtaceae) are found only in Brazilian sandy coastal environments, ${ }^{1}$ also referred to as "restingas", which are ecosystems constantly subjected to the impact of

*e-mail: alicesato@unirio.br human occupation and to water and nutritional deficiencies due to sandy soil. ${ }^{2}$

Eugenia neonitida is commonly known as "pitangão", while the common name for $E$. rotundifolia is "araponga". Both species produce berry fruits, and E. neonitida ones are eatable, extremely aromatic, and used for beverage preparation. ${ }^{3}$ They also possess numerous translucent dots in the whole plant defined as secretory cavities of the 
essential oils. ${ }^{4}$ The composition of Eugenia leaf essential oils has been studied and many authors have reported the occurrence of $\alpha$-pinene, $\alpha$-copaene, $\beta$-elemene, alloaromadendrene, $\delta$-cadinene, spathulenol, globulol, epiglobulol, $\beta$-caryophyllene and $\alpha$-humulene. These last two components are known for their anti-inflammatory properties and were identified in the essential oils of more than 30 Eugenia species. ${ }^{5,6}$ However, neither E. neonitida nor $E$. rotundifolia essential oils composition was found in the literature.

This paper appraises the composition of fresh and dried leaves essential oils of E. neonitida and E. rotundifolia. In addition, variation in the amounts of fresh leaves essential oils major compounds was evaluated trimestrially seeking to correlate it with abiotic factors or with the plant's phenologic stage. The antioxidant activity of dried leaves essential oils and the leaves histochemistry were also reported.

\section{Experimental}

\section{Abiotic factors}

Data referring to the abiotic factors medium temperature $\left({ }^{\circ} \mathrm{C}\right)$ and precipitation $(\mathrm{mm})$ in Rio de Janeiro City during 2009 were obtained from Instituto Brasileiro de Meteorologia (INMET). ${ }^{7}$ According to that, in Rio de Janeiro the medium temperature varied in the range of $22-29^{\circ} \mathrm{C}$ and precipitation varied from 51 to $211 \mathrm{~mm}$. Usually, tropical climate seasons are not well defined, occurring only periods of months colder and drier than others, as shown by Gaussen-Gagnouls ombrotermic diagram built with the climatological normals of medium temperature $\left({ }^{\circ} \mathrm{C}\right)$ and precipitation (mm) during the period between 1961-1990. ${ }^{7}$ However, analysis of the Gaussen-Gagnouls ombrotermic diagram built with the same abiotic factors during 2009 has shown a variation of this pattern, indicating the occurrence of a dry season from May to August in Rio de Janeiro.?

\section{Plant material}

Eugenia neonitida and E. rotundifolia leaves were obtained from georeferenced individuals in a sandy coastal environment located in Rio de Janeiro City called "Restinga

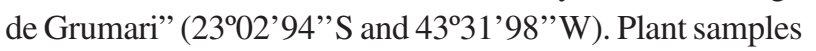
were collected trimestrially in a way that two collections occurred in drier and colder months (May and August) and both the other collections were carried out in wetter and hotter months (February and November). During the collection of the plant material the phenologic stages (presence of leaves, flowers and fruits) were observed. ${ }^{8}$ Voucher specimens were deposited at Universidade Federal do Estado do Rio de Janeiro Herbarium (HUNI646 and HUNI650).

\section{Essential oil extraction, seasonal variation and statistical analysis}

Fresh leaves collected from four of both species georeferenced individuals during the months of analysis were subjected to hydrodistillation for $3 \mathrm{~h}$ using a Clevenger apparatus. Air dried leaves collected in November from five individuals of both species were likewise subjected to hydrodistillation. The essential oils obtained from dried leaves were weighted and the extraction yields expressed in relation to dry leaf mass were calculated.

A linear correlation test was used in order to detect any influence of medium temperature and precipitation on the percentages of the major compounds present in both species essential oils from the February, May, August and November 2009 collections. Likewise, major compounds of the essential oils were correlated with the phenologic stages of the collected georeferenced individuals. A $t$ student test was also used to detect seasonal variation in the essential oils major compounds in May (cold and dry month) and in November (hot and wet month). In this case, the results presented here are the means of four replicate experiments. Statistical analyses were conducted using the software GraphPad Instat.

\section{Gas chromatography-mass spectrometry (GC-MS)}

The leaf essential oils were analyzed by high resolution gas chromatography with a flame ionization detector (GC-FID), and high resolution gas chromatography-mass spectrometry (GC-MS). For the GC-FID analysis a Varian Star 3350 apparatus equipped with a silica capillary column Quadrex Inc. 007-1 $(50 \mathrm{~m} \times 0.25 \mathrm{~mm}$ id; $0.5 \mu \mathrm{m}$ film thickness) was used. For the GC-MS analysis a Varian Star CP3800 apparatus equipped with a triple quadrupole trap detector (Varian Star 12000L) and a fused silica capillary column Varian Inc. VF5-ms (30 m $\times 0.25 \mathrm{~mm}$ id; $0.25 \mu \mathrm{m}$ film thickness) operating in electron impact mode $(70 \mathrm{eV})$ were used. The carrier gas was $\mathrm{H}_{2}$ in GC-FID and $\mathrm{He}$ in GC-MS. Similar chromatographic conditions were used in both analyses: injector and detector temperature was $250{ }^{\circ} \mathrm{C}$; the column temperature was programmed to hold isothermal at $40{ }^{\circ} \mathrm{C}$ for $2 \mathrm{~min}$, then heating rate of $6{ }^{\circ} \mathrm{C} \min ^{-1}$ to $250{ }^{\circ} \mathrm{C}$, and at the end hold isothermal for $5 \mathrm{~min}$. Injection volume was $0.5 \mu \mathrm{L}$ of essential oil solution in $\mathrm{CH}_{2} \mathrm{Cl}_{2}$, in splitless mode.

Compounds identification was accomplished by comparing the obtained mass spectra with reference data 
from National Institute of Standards and Technology database (NIST 05 2.0d), and also by comparing the experimental Kovat's retention index $\left(\mathrm{IK}_{\mathrm{C}}\right)$ calculated from a $\mathrm{C}_{7}-\mathrm{C}_{26} n$-alkanes series with literature data. ${ }^{9}$ The chemical compound amounts were expressed as percentage, calculated from the normalized area data.

\section{Antioxidant activity}

The radical scavenging activity was measured according to 2,2-diphenyl-1-picrylhydrazyl (DPPH') method. ${ }^{10,11}$ The essential oils obtained from dried leaves of both species from November collection were diluted in ethanol to final concentrations of 1.000, 250, and $125 \mu \mathrm{g} \mathrm{mL}^{-1}$. A $0.37 \mathrm{~mL}$ sample of $0.1 \mathrm{mmol} \mathrm{L}^{-1} \mathrm{DPPH}^{\bullet}$ (Sigma, 90\% purity) solution in ethanol was added to $0.93 \mathrm{~mL}$ aliquots of essential oil solutions. Ethanol $(0.37 \mathrm{~mL})$ plus essential oil solution $(0.93 \mathrm{~mL})$ was used as blank, while $\mathrm{DPPH}^{\circ}$ solution $(0.37 \mathrm{~mL})$ plus ethanol $(0.93 \mathrm{~mL})$ was used as negative control. After $30 \mathrm{~min}$ of reaction in the dark and at room temperature the absorbance values (sample, blank and negative control) were measured at $517 \mathrm{~nm}$. As positive control a 2,6-di-tert-butyl-4-methylphenol (BHT, Fluka, $\geq 99.0 \%$ purity) solution in the same concentration of the essential oil solutions was used.

The percentage of antioxidant activity (AA\%) was calculated using the equation: $\mathrm{AA} \%=100-\left\{\left[\left(\mathrm{Abs}_{\text {sample }}-\right.\right.\right.$ $\left.\left.\left.\mathrm{Abs}_{\text {blank }}\right) \times 100\right] / \mathrm{Abs}_{\text {control }}\right\}$. Each assay was repeated three times and results are means \pm standard deviation. Efficient concentration values $\left(\mathrm{EC}_{50}\right)$ were calculated by linear regression of the data.

\section{Histochemistry}

Fresh leaves from both species were transversally hand sectioned and stained with $1 \%$ alcian blue and $1 \%$ basic fucsin in 50\% ethanol. The following histochemical tests were also applied to transversal sections of fresh leaves: Sudan III and IV, ${ }^{12}$ Sudan black $\mathrm{B}^{13}$ and Sudan red $\mathrm{B}^{14}$ for lipids; Nile blue sulphate for acid and neutral lipids; ${ }^{15}$ 2,4-dinitrophenylhydrazine for terpenoids with carbonyl group ${ }^{16}$ and Oil Red $\mathrm{O}$ for rubber. ${ }^{17}$ The observations were captured in an Olympus BX41 light microscope.

\section{Results and Discussion}

Composition and seasonal variation of fresh leaves essential oils

Altogether, 41 compounds were identified in E. neonitida fresh leaves essential oil, and 40 compounds in E. rotundifolia (Tables 1 and 2). Essential oils major compounds were bicyclogermacrene, germacrene $\mathrm{D}$ and $\beta$-caryophyllene in E. neonitida, and $\alpha$-pinene, $\beta$-pinene and $\beta$-caryophyllene in E. rotundifolia. These compounds are commonly identified in Eugenia leaves essential oils. ${ }^{18}$

The essential oils of both species are rich in cyclic compounds, especially hydrocarbons. A few alcohols and one oxide derivative were also identified. The essential oils compounds were grouped into fourmajorclasses: hydrocarbon monoterpenes, oxygenated monoterpenes, hydrocarbon sesquiterpenes, oxygenated sesquiterpenes and others, category in which non terpenoid compounds were included. Eugenia neonitida essential oil was rich in hydrocarbon sesquiterpenes throughout the analysis (Figure 1A), while hydrocarbon monoterpenes were the major compounds in the E. rotundifolia essential oil (Figure 1B).

The seasonal variation in the six major compounds of the essential oils of both species was addressed through the analysis of their relative abundance and is represented in Figures 1 and 2. In E. neonitida a decrease was observed in the amount of bicyclogermacrene, globulol, viridiflorol and epi-globulol during the coldest and driest month (August), while the amount of germacrene D increased remarkably (Figure 1A). These five mentioned compounds plus $\beta$-caryophyllene added up more than $50 \%$ of E. neonitida essential oil (Table 1). In E. rotundifolia a decrease was observed in the amount of $\beta$-caryophyllene, spathulenol and $\alpha$-cadinol accompanied by an increase in the amount of $\alpha$-pinene and $\beta$-pinene in August (Figure 1B). These last remarked components plus limonene added up more than $60 \%$ of E. rotundifolia leaves essential oil (Table 2).

Besides the mentioned quantitative variation, qualitative differences were also observed in both species essential oils. For instance, in E. neonitida essential oil $\beta$-copaene was not identified in February and May, while $\alpha$-pinene, cyperene, valencene, and ledol were not identified in August (Table 1). In $E$. rotundifolia essential oil, $\alpha$-cubebene, $\alpha$-gurjunene, $\beta$-copaene and spathulenol were not identified in August (Table 2).

Since small differences in the amounts of the major compound of both species essential oils were detected, these values were statistically correlated to the phenologic stages of the collected individuals and the abiotic factors medium temperature $\left({ }^{\circ} \mathrm{C}\right)$ and precipitation $(\mathrm{mm})$. In relation to phenologic stages, leaves were observed in both species during the four months of analysis. Flowers and fruits were observed only in E. neonitida in February and November.

Statistically significant correlation between the amounts of major components of E. neonitida and E. rotundifolia essential oils with either the phenologic stage or the medium 
Table 1. Seasonal variation in chemical composition of the essential oil of Eugenia neonitida fresh leaves, chemical composition of dried leaves essential oil, and calculated Kovat's retention index $\left(\mathrm{KI}_{\mathrm{C}}\right)$. Entries are normalized area values

\begin{tabular}{|c|c|c|c|c|c|c|}
\hline \multirow[b]{2}{*}{ Compounds } & \multirow[b]{2}{*}{$\mathrm{KI}_{\mathrm{C}}$} & \multicolumn{4}{|c|}{ Fresh leaves } & \multirow{2}{*}{$\begin{array}{c}\text { Dried leaves } \\
\text { Nov }\end{array}$} \\
\hline & & Feb & May & Aug & Nov & \\
\hline Ethyl acetate & 824 & 0.8 & 0.6 & - & 1.0 & - \\
\hline (E)-3-Hexen-1-ol & 837 & 0.5 & 0.2 & - & 0.6 & - \\
\hline$\alpha$-Pinene & 931 & 3.1 & 1.8 & - & 0.7 & 2.4 \\
\hline Terpinolene & 1082 & - & - & - & - & 0.4 \\
\hline$\delta$-Elemene & 1337 & 0.8 & 0.9 & 0.9 & 1.2 & 1.6 \\
\hline$\alpha$-Copaene & 1379 & 1.8 & 2.8 & 3.6 & 3.4 & 5.2 \\
\hline$\beta$-Elemene & 1390 & 1.3 & 1.3 & 1.2 & 1.2 & 1.5 \\
\hline Cyperene & 1397 & 0.5 & 0.4 & - & 0.1 & 0.5 \\
\hline$\alpha$-Gurjunene & 1414 & 1.1 & 0.7 & 0.6 & 1.1 & 1.4 \\
\hline$\beta$-Caryophyllene & 1423 & 6.7 & 9.2 & 9.9 & 11.0 & 12.5 \\
\hline$\beta$-Copaene & 1433 & - & - & 0.7 & 0.1 & - \\
\hline Aromadendrene & 1444 & 2.6 & 1.6 & 0.9 & 1.6 & - \\
\hline (Z)- $\beta$-Farnesene & 1446 & 1.1 & 1.0 & 0.7 & 0.8 & 1.9 \\
\hline (E)- $\alpha$-Bergamotene & 1449 & - & 0.3 & - & 0.1 & 1.2 \\
\hline$\alpha$-Himachalene & 1456 & 3.4 & 3.2 & 4.5 & 3.0 & 3.5 \\
\hline (E)-9-epi-Caryophyllene & 1460 & - & 0.2 & - & - & - \\
\hline$\alpha$-Humulene & 1464 & 2.8 & 2.8 & 2.5 & 3.0 & 3.9 \\
\hline$\beta$-Chamigrene & 1474 & 1.3 & 1.2 & 1.7 & 0.9 & 1.1 \\
\hline Germacrene D & 1481 & 8.2 & 5.7 & 18.7 & 6.0 & 6.5 \\
\hline Valencene & 1491 & 1.4 & 1.8 & - & 0.6 & 0.9 \\
\hline Bicyclogermacrene & 1496 & 18.7 & 16.3 & 15.2 & 21.0 & 24.3 \\
\hline$\beta$-Bisabolene & 1501 & 2.5 & 2.0 & 2.4 & 2.1 & 2.7 \\
\hline$(\mathrm{E}, \mathrm{E})-\alpha$-Farnesene & 1510 & 0.8 & 0.7 & 1.1 & 0.6 & 0.8 \\
\hline$\delta$-Cadinene & 1517 & 3.5 & 2.5 & 5.4 & 4.8 & 5.9 \\
\hline$\beta$-Sesquifelandrene & 1521 & - & 0.9 & - & - & - \\
\hline (E)- $\gamma$-Bisabolene & 1525 & 0.8 & 0.4 & 0.8 & 0.6 & 0.9 \\
\hline Germacrene B & 1554 & - & 0.2 & - & 0.1 & 1.0 \\
\hline Ledol & 1564 & 0.7 & 0.7 & - & 0.7 & 0.4 \\
\hline Spathulenol & 1570 & 2.8 & 4.0 & 2.8 & 0.8 & 1.7 \\
\hline Caryophyllene oxide & 1577 & - & 1.2 & 0.5 & 0.2 & - \\
\hline Globulol & 1581 & 6.0 & 6.3 & 2.7 & 6.6 & 3.1 \\
\hline Viridiflorol & 1589 & 9.1 & 7.5 & 3.5 & 7.7 & 4.6 \\
\hline Guaiol & 1596 & 1.0 & 0.9 & 0.5 & 1.0 & 0.6 \\
\hline epi-Globulol & 1599 & 4.9 & 5.2 & 2.8 & 4.4 & 3.2 \\
\hline 5-epi-7- $\alpha$-Eudesmol & 1616 & 1.3 & 1.1 & 0.8 & 1.2 & 0.6 \\
\hline 1,10-di-epi-Cubenol & 1623 & - & 0.3 & - & 0.2 & - \\
\hline 1-epi-Cubenol & 1626 & 0.5 & 0.9 & 0.5 & 0.2 & - \\
\hline T-Muurolol & 1631 & 2.8 & 2.6 & 3.1 & 0.7 & - \\
\hline (Z)-Cadin-4-en-7-ol & 1633 & 0.5 & 1.2 & 0.5 & 1.9 & 1.4 \\
\hline$\alpha$-Cadinol & 1644 & 4.5 & 5.4 & 5.1 & 3.8 & 1.8 \\
\hline$\beta$-Bisabolol & 1658 & 0.5 & 0.7 & 0.6 & 0.4 & - \\
\hline Total & & 98.5 & 96.8 & 94.3 & 95.3 & 97.3 \\
\hline Hydrocarbon monoterpenes & & 3.1 & 1.8 & - & 0.7 & 2.7 \\
\hline Oxygenated monoterpenes & & - & - & - & - & - \\
\hline Hydrocarbon sesquiterpenes & & 59.4 & 56.0 & 70.7 & 63.3 & 77.2 \\
\hline Oxygenated sesquiterpenes & & 34.7 & 38.2 & 23.6 & 29.7 & 17.4 \\
\hline Others & & 1.3 & 0.8 & - & 1.6 & - \\
\hline Oil yield / (\%) & & - & - & - & - & 0.1 \\
\hline
\end{tabular}


Table 2. Seasonal variation in chemical composition of the essential oil of Eugenia rotundifolia fresh leaves, chemical composition of dried leaves essential oil, and calculated Kovat's retention index $\left(\mathrm{KI}_{\mathrm{C}}\right)$. Entries are normalized area values

\begin{tabular}{|c|c|c|c|c|c|c|}
\hline \multirow[b]{2}{*}{ Compounds } & \multirow[b]{2}{*}{$\mathrm{KI}_{\mathrm{C}}$} & \multicolumn{4}{|c|}{ Fresh leaves } & \multirow{2}{*}{$\begin{array}{c}\text { Dried leaves } \\
\text { Nov }\end{array}$} \\
\hline & & Feb & May & Aug & Nov & \\
\hline (E)-3-Hexen-1-ol & 841 & - & - & 0.3 & - & - \\
\hline$\alpha$-Pinene & 933 & 27.4 & 33.7 & 34.4 & 19.7 & 29.7 \\
\hline$\beta$-Pinene & 973 & 31.9 & 29.8 & 34.1 & 20.6 & 25.5 \\
\hline Myrcene & 982 & 0.8 & 0.7 & 0.7 & 0.3 & 0.5 \\
\hline Limonene & 1021 & 4.2 & 2.9 & 2.3 & 1.9 & 2.0 \\
\hline Terpinolene & 1079 & 0.5 & 0.4 & 0.4 & 0.1 & - \\
\hline$\alpha$-Terpineol & 1174 & 2.9 & 1.3 & 2.3 & 1.6 & 0.9 \\
\hline$\alpha$-Cubebene & 1351 & 0.5 & 0.2 & - & 0.3 & 0.5 \\
\hline$\alpha$-Copaene & 1379 & 0.4 & - & - & 0.4 & - \\
\hline Cyperene & 1398 & - & - & - & - & 0.6 \\
\hline$\alpha$-Gurjunene & 1413 & 1.0 & 0.4 & - & 0.5 & 0.8 \\
\hline$\beta$-Caryophyllene & 1423 & 8.0 & 7.1 & 3.6 & 11.7 & 8.5 \\
\hline$\beta$-Copaene & 1434 & 0.5 & 0.1 & - & 0.3 & - \\
\hline$\beta$-Gurjunene & 1437 & 0.5 & 0.3 & - & 0.5 & - \\
\hline Aromadendrene & 1443 & 1.2 & 0.9 & 0.7 & 1.7 & 1.9 \\
\hline (E)- $\alpha$-Bergamotene & 1450 & 0.6 & 0.3 & - & 0.3 & 0.6 \\
\hline$\alpha$-Himachalene & 1455 & 0.7 & 0.7 & 0.4 & 1.1 & 0.9 \\
\hline (E)-9-epi-Caryophyllene & 1463 & 0.7 & 0.4 & - & 0.7 & 0.8 \\
\hline (E)-Cadina-1(6).4-diene & 1472 & 1.0 & 0.4 & - & 0.8 & 0.5 \\
\hline$\beta$-Chamigrene & 1477 & - & 0.2 & - & 0.4 & - \\
\hline Valencene & 1491 & - & 0.9 & 0.7 & - & - \\
\hline Bicyclogermacrene & 1495 & 1.5 & 1.8 & 1.8 & 1.2 & 1.6 \\
\hline$\beta$-Bisabolene & 1501 & 0.5 & 0.3 & - & 1.1 & 3.0 \\
\hline$(E, E)-\alpha$-Farnesene & 1513 & 0.7 & 0.6 & - & 0.5 & 0.5 \\
\hline$\delta$-Cadinene & 1517 & 1.9 & 1.3 & 0.8 & 1.8 & 1.7 \\
\hline$\beta$-Sesquifelandrene & 1521 & 0.4 & 0.7 & 1.0 & 3.1 & 2.1 \\
\hline (E)-Cadina-1(2).4-diene & 1528 & 1.3 & 0.8 & 0.6 & 1.3 & 1.7 \\
\hline Germacrene B & 1557 & 0.5 & 0.4 & 0.4 & 0.5 & 2.2 \\
\hline Spathulenol & 1570 & 1.5 & 1.9 & - & 2.3 & 1.6 \\
\hline Caryophyllene oxide & 1576 & 0.6 & 0.9 & 2.1 & 2.7 & - \\
\hline Globulol & 1581 & 2.2 & 1.4 & 1.7 & 2.7 & 0.8 \\
\hline Viridiflorol & 1588 & 0.6 & 0.9 & 0.3 & 2.0 & 1.1 \\
\hline epi-Globulol & 1599 & 0.4 & 0.4 & 0.5 & 0.9 & 0.9 \\
\hline 5-epi-7- $\alpha$-Eudesmol & 1616 & 0.4 & 0.5 & 0.7 & 1.1 & 0.8 \\
\hline 1.10-di-epi-Cubenol & 1621 & 1.3 & 1.1 & 1.2 & 1.8 & 0.9 \\
\hline 1-epi-Cubenol & 1626 & - & 0.3 & 0.4 & - & - \\
\hline T-Muurolol & 1631 & 1.0 & 0.7 & 0.9 & 1.2 & 0.6 \\
\hline (Z)-Cadin-4-en-7-ol & 1637 & 0.8 & 0.6 & 0.3 & 1.3 & 0.5 \\
\hline$\alpha$-Cadinol & 1643 & 1.1 & 1.5 & 0.6 & 3.0 & 1.2 \\
\hline$\beta$-Bisabolol & 1656 & 0.4 & 0.4 & 2.3 & 1.7 & 0.7 \\
\hline Total & & 100.0 & 97.1 & 95.4 & 93.1 & 95.4 \\
\hline Hydrocarbon monoterpenes & & 64.9 & 67.6 & 71.9 & 42.7 & 57.7 \\
\hline Oxygenated monoterpenes & & 3.0 & 1.3 & 2.3 & 1.7 & 0.9 \\
\hline Hydrocarbon sesquiterpenes & & 21.8 & 17.8 & 9.9 & 28.1 & 27.8 \\
\hline Oxygenated sesquiterpenes & & 10.4 & 10.4 & 11.1 & 20.7 & 9.0 \\
\hline Others & & - & - & 0.3 & - & - \\
\hline Oil yield / (\%) & & - & - & - & - & 0.4 \\
\hline
\end{tabular}


temperature was not detected. Statistically significant positive correlations were detected only between the precipitation and the compounds biclyclogermacrene $\left(\mathrm{r}=0.987 ; \mathrm{P}=0.013^{*}\right)$ in E. neonitida essential oil (Figure 2A), and $\beta$-caryophyllene $\left(\mathrm{r}=0.973 ; \mathrm{P}=0.057^{*}\right)$ in E. rotundifolia (Figure $2 \mathrm{~B}$ ). Additionally, one statistically significant negative correlation was detected also between the precipitation and the $\alpha$-pinene in $E$. rotundifolia essential oil $\left(\mathrm{r}=-0.984 ; \mathrm{P}=0.016^{*}\right)$ (Figure 2B).

Thus, the phenologic stage and medium temperature do not seem to influence both species essential oils composition. Likewise, according to the $t$ student test, statistically significant differences in the composition of essential oils of leaves collected during the coldestdriest and the hottest-wettest periods of the year were not detected. Similar observations were found by other researchers. ${ }^{19}$

Tropical climate seasons are not well defined. In Rio de Janeiro, for instance, 2009 monthly medium temperature and precipitation varied only from 22 to $29^{\circ} \mathrm{C}$ and from 51 to $211 \mathrm{~mm}$, respectively, as mentioned earlier. ${ }^{7}$ This small variation does not establish the occurrence of spring, summer, autumn and fall, it only indicated the occurrence of a dry season from May to August. These abiotic factors are even more stable in sandy coastal environments such as "restinga de Grumari," characterized by high temperatures and low water availability, ${ }^{2}$ which probably contributed for the small variation observed in the essential oils of both species.

However, statistically significant correlation was detected between precipitation and one out of six major compounds of E. neonitida essential oil and two out of six major compounds in the essential oil obtained from E. rotundifolia leaves. Even though only three statistically significant correlations were detected, a noteworthy decrease occurred in the percentages of viridiflorol, globulol and epi-globulol in E. neonitida essential oil and in the percentages of spathulenol and $\alpha$-cadinol in E. rotundifolia essential oil in August, the month with the lowest precipitation level. In fact, many authors have linked the observed differences in the amount of essential oil compounds with season changes. ${ }^{20-22}$

\section{Composition and antioxidant activity of dried leaves essential oils}

The essential oils obtained from dried leaves collected from E. neonitida and E. rotundifolia in November are very similar to the essential oils obtained from fresh leaves. Most of their major compounds are also the major compounds in the essential oils obtained from fresh leaves (Tables 1 and 2). Bicyclogermacrene, $\beta$-caryophyllene and germacrene D are also the major compounds in E. neonitida dried leaves essential oil (Table 1). Likewise, $\alpha$-pinene, $\beta$-pinene and $\beta$-caryophyllene are the major compounds in E. rotundifolia dried leaves essential oil (Table 2). Eugenia neonitida and E. rotundifolia dried leaves essential oils yields were $0.1 \%$ and $0.4 \%$, respectively (Tables 1 and 2).

However, some qualitative and quantitative differences were observed when comparing both species fresh and dried leaves essential oils. In E. neonitida, for instance, aromadendrene and $\beta$-bisabolol were observed only in fresh leaves essential oil, while globulol, viridiflorol and $\alpha$-cadinol percentages in dried leaves essential oil were inferior when compared to fresh leaves essential oil (Table 1). In E. rotundifolia, terpinolene and $\beta$-gurjunene were detected only in fresh leaves essential oil, while $\beta$-bisabolene and germacrene $B$ percentages in dried leaves essential oil were superior when compared to fresh leaves essential oil (Table 2).

Another noteworthy comment is the occurrence of components such as terpinolene (E. neonitida) and cyperene (E. rotundifolia) only in the essential oils obtained from dried leaves, what may be explained by the superior number of individuals from which leaves were collected for essential oil extraction.

Eugenia neonitida and E. rotundifolia dried leaves essential oils exhibited weak antioxidant activities according to the $\mathrm{DPPH}^{\bullet}$ assay. $\mathrm{EC}_{50}$ values were $8.6 \mathrm{mg} \mathrm{mL}^{-1}$ for E. neonitida and $5.8 \mathrm{mg} \mathrm{mL}^{-1}$ for E. rotundifolia. Because of the similarities in the composition of E. neonitida, E. rotundifolia, and other Eugenia species essential oils, it is possible to predict that the antioxidant activity of the last ones will also be weak. The exception is E. caryophyllata, commonly known as clove, whose essential oil exhibits strong antioxidant activity $\left(\mathrm{EC}_{50}=0.2 \mu \mathrm{g} \mathrm{mL}^{-1}\right)$ due to the presence of eugenol. ${ }^{5,6,23}$

\section{Histochemistry}

The presence of lipids in secretory cavities and parenchyma cells of both species was detected by Sudan III, IV, black B, and red B. Nile blue sulphate indicated the presence of neutral lipids (such as hydrocarbons) also in both species parenchyma cells and secretory cavities. It also detected the presence of acid lipids (such as like fatty acids or phospholipids) only in E. rotundifolia secretory cavities. Rubber was detected by Oil Red O in both species secretory cavities and parenchyma cells, indicating once more the complexity of these structures content. Finally, 2,4-dinitrophenylhydrazine test used to detect the presence of terpenoids with carbonyl group did not react with the secretory cavities content, certifying the GC-FID and GC-MS analyses. 
A)

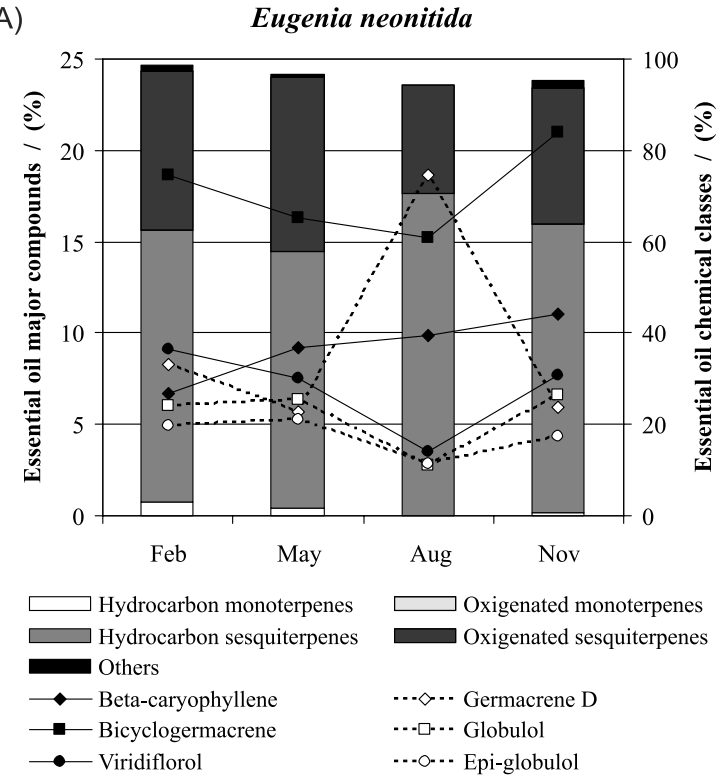

B)

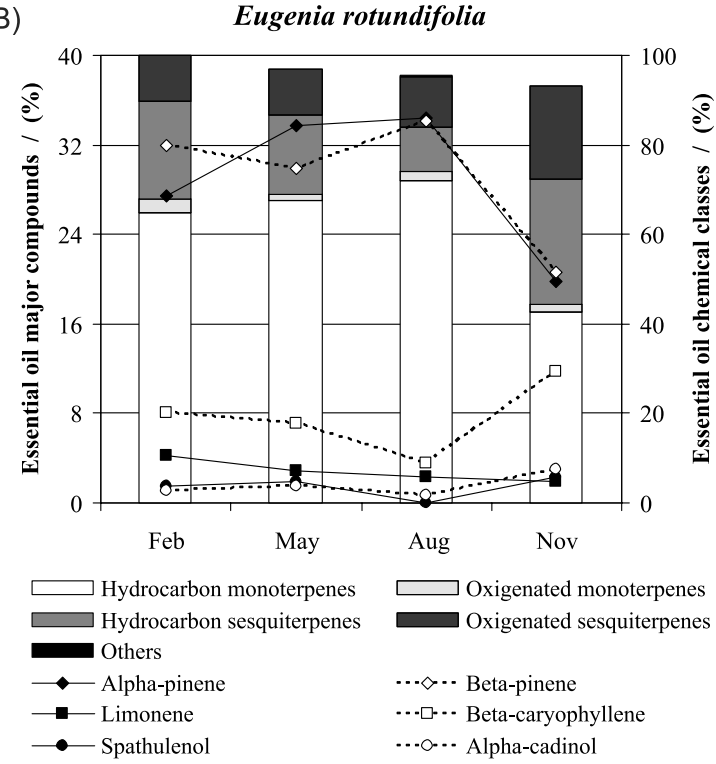

Figure 1. Seasonal variation in relative percentages of Eugenia neonitida (A) and Eugenia rotundifolia (B) essential oil major compounds and chemical classes during the analysis.

\section{Conclusions}

The major compounds in the essential oils of fresh leaves were bicyclogermacrene, germacrene D and $\beta$-caryophyllene, in E. neonitida, and $\alpha$-pinene, $\beta$-pinene and $\beta$-caryophyllene in E. rotundifolia. The essential oils of both species are mainly constituted by cyclic hydrocarbons and cyclic alcohols, but also possess cyclic oxides and non terpenoid aliphatic compounds. Eugenia neonitida essential oil is rich in sesquiterpenes, while E. rotundifolia's is rich in monoterpenes. Despite the small quantitative and qualitative variations in both species essential oils, statistically significant correlation

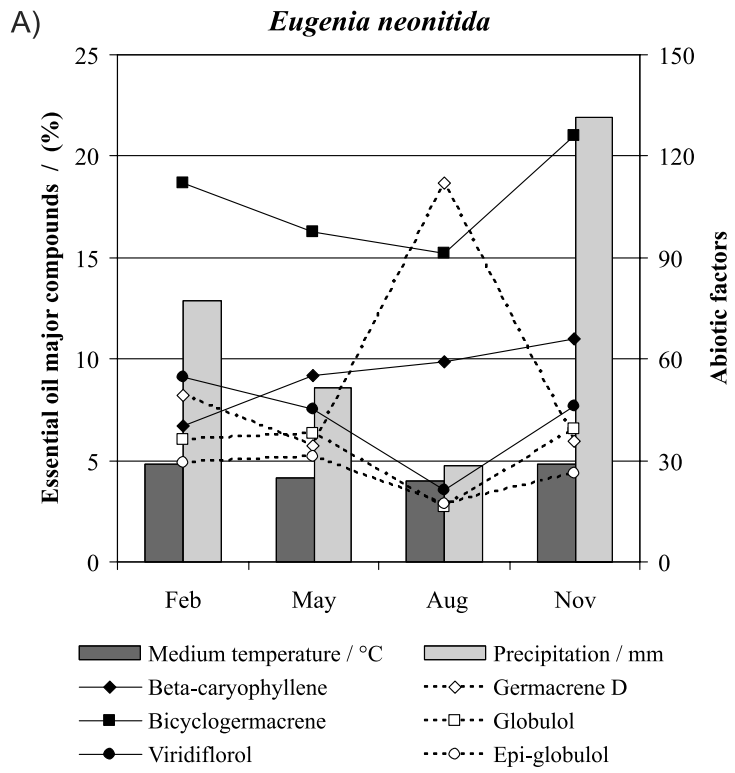

B)

B) Eugenia rotundifolia

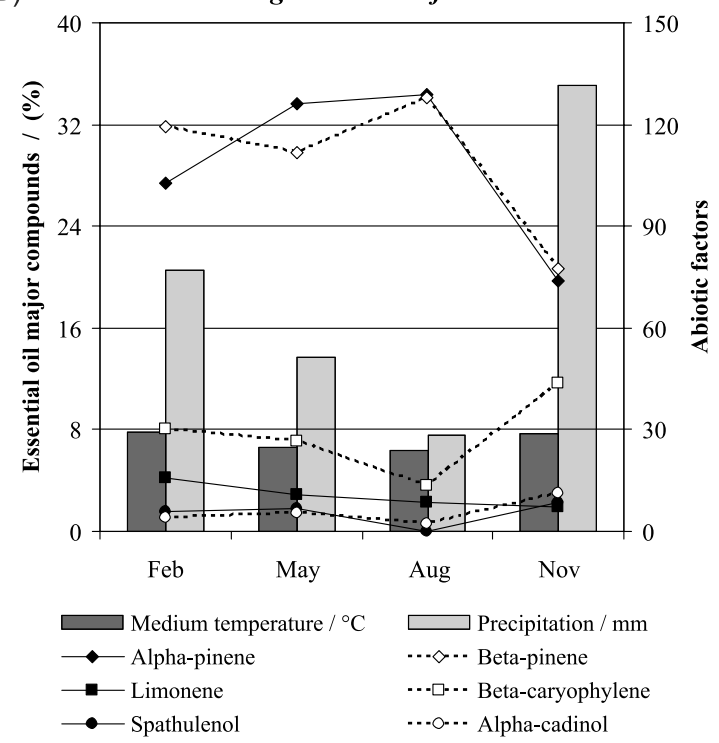

Figure 2. Seasonal variation in relative percentages of Eugenia neonitida (A) and Eugenia rotundifolia (B) essential oil major compounds during the analysis and the abiotic factors medium temperature and precipitation. ${ }^{7}$

with either phenologic stages or medium temperature and essential oil major components was not detected. Statistically significant seasonal difference in these last was also not detected. Precipitation, however, seems to be related to the percentages of some essential oils major components. The essential oils of both species dried leaves are quite similar to the essential oils obtained from fresh leaves and exhibited weak antioxidant activity. The leaves' histochemistry certified the GC-FID and GC-MS analyses and also attested the complexity of the solutions stored in secretory cavities and parenchyma cells: besides hydrocarbon and alcohol lipids, they may possess fatty acids, phospholipids and rubber. 


\section{Supplementary Information}

Gaussen-Gagnouls ombrotermic diagrams, GC-FID chromatograms, and histochemistry imaging are available free of charge at http://jbcs.sbq.org.br as a PDF file.

\section{Acknowledgments}

The authors thank Fundação de Amparo à Pesquisa do Estado do Rio de Janeiro (FAPERJ) for the financial support and Conselho Nacional de Desenvolvimento Científico e Tecnológico (CNPq) for Master's scholarship of the first author. We also thank Universidade Federal do Estado do Rio de Janeiro (UNIRIO) and Programa de Pós-Graduação em Biotecnologia Vegetal (PPBV-UFRJ) for the logistical support.

\section{References}

1. Souza, M. C.; Morim, M. P.; Acta Bot. Bras. 2008, 22, 652.

2. Henriques, R. P. B.; Araújo, D. S. D.; Hay, J. D.; Rev. bras. Bot. 1986, 9, 173.

3. Vilar, J. S.; Silva, A. C. A.; Coelho, M. R.; Silva, A. L. G.; Srur, A. U. O. S.; Rev. Bras. Frutic. 2006, 28, 536.

4. Fontenelle, G. B.; Costa, C. G.; Machado, R. D.; Bot. J. Linn. Soc. 1994, 115, 111.

5. Menichini, F.; Conforti, F.; Rigano, D.; Formisano, C.; Piozzi, F.; Senatore, F.; Food Chem. 2009, 115, 679.

6. Passos, G. F.; Fernandes, E. S.; Cunha, F. M.; Ferreira, J.; Pianowski, L. F.; Campos, M. M.; Calixto, J. B.; J. Ethnopharmacol. 2007, 110, 323.

7. http://www.inmet.gov.br accessed in March 2011.
8. Bencke, C. S. C.; Morellato, L. P. C.; Rev. bras. Bot. 2007, 25, 269.

9. Adams, R. P.; Identification of Essential Oil Components by Gas Chromatography/Quadrupole Mass Spectrometry; Allured Publishing Corporation: Illinois, 2001.

10. Mensor, L. L.; Menezes, F. S.; Leitão, G. G.; Reis, A. S.; Santos, T. C.; Coube, C. S.; Leitão, S. G.; Phytother. Res. 2001, 15, 127.

11. Blois, M. S.; Nature 1958, 181, 1199.

12. Johansen, D. A.; Plant Microtechnique; McGrow-Hill Book Co.: New York, 1940.

13. Pearse, A. G. E.; Histochemistry Theoretical and Applied, $4^{\text {th }}$ ed.; Longman Group Limited: London, 1980.

14. Brundrett, M. C.; Kendrick, B.; Peterson, C. A.; Biotech. Histochem. 1991, 66, 111.

15. Cain, A. J.; Q. J. Microsc. Sci. 1947, 88, 383.

16. Ganter, P.; Jollés, G.; Histologie Normale et Patologique; Gauthier: Paris, 1969.

17. Jayabalan, M.; Shah, J. J.; Biotech. Histochem. 1986, 61, 303.

18. Cole, R. A.; Haber, W. A.; Setzer, W. N.; Biochem. Syst. Ecol. 2007, 35, 877.

19. Cerqueira, M. D.; Marques, E. J.; Martins, D.; Roque, N. F.; Cruz, F. G.; Guedes, M. L. S.; Quim. Nova 2009, 32, 1544.

20. Stefanello, M. E. A.; Wisniewski Júnior, A.; Simionatto, E. L.; Cervi, A. C.; Lat. Am. J. Pharm. 2009, 28, 449.

21. Lima, N. P.; Cerqueira, S. H. F.; Fávero, O. A.; Romoff, P.; Lago, J. H. G.; J. Essent. Oil Res. 2008, 20, 223.

22. Sangwan, N. S.; Farooqi, F. S.; Sangwan, R. S.; Plant Growth Regul. 2001, 32, 3.

23. Chaieb, K.; Zmantar, T.; Ksouri, R.; Hajlaoui, H.; Mahdouani, K.; Abdely, C.; Bakhrouf, A.; Mycoses 2007, 50, 403.

Submitted: September 13, 2010

Published online: May 10, 2011 


\title{
Eugenia neonitida Sobral and Eugenia rotundifolia Casar. (Myrtaceae) Essential Oils: Composition, Seasonality Influence, Antioxidant Activity and Leaf Histochemistry
}

\author{
Anna C. A. Defaveri, ${ }^{a, b}$ Alice Sato, ${ }^{*, a, b}$ Leandro B. Borré, ${ }^{c}$ Daniel L. M. Aguiar, ${ }^{c}$ \\ Rosane A. S. San Gil, ${ }^{c}$ Rosani C. O. Arruda ${ }^{d}$ and Carlos A. S. Riehl
}

${ }^{a}$ Centro de Ciências da Saúde, Universidade Federal do Rio de Janeiro, Av. Carlos Chagas Filho, 373,

Bloco K, Cidade Universitária, Ilha do Fundão, 21941-590 Rio de Janeiro-RJ, Brazil

${ }^{b}$ Instituto de Biociências, Universidade Federal do Estado do Rio de Janeiro, Av. Pasteur 458, Urca, 22290-240 Rio de Janeiro-RJ, Brazil

'Instituto de Química, Universidade Federal do Rio de Janeiro, Av. Athos da Silveira Ramos, 149,

Bloco A, Cidade Universitária, Itha do Fundão, 21949-900 Rio de Janeiro-RJ, Brazil

${ }^{d}$ Centro de Ciências Biológicas e da Saúde, Universidade Federal de Mato Grosso do Sul, Av. Senador Felinto Müller s/n, Cidade Universitária, 79070-900 Campo Grande-MS, Brazil

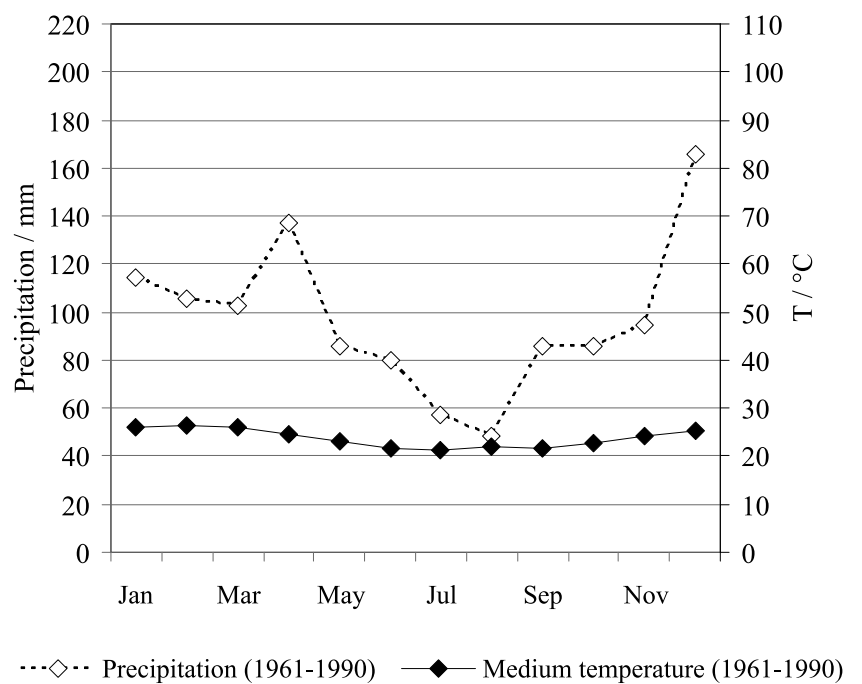

A

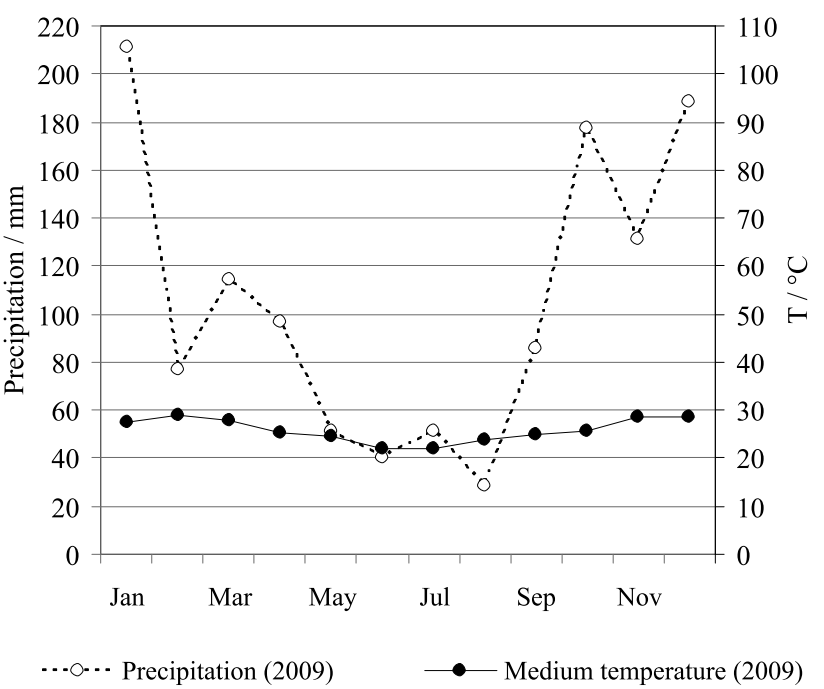

B

Figure S1. Gaussen-Gagnouls ombrotermic diagrams built using medium temperature $\left({ }^{\circ} \mathrm{C}\right)$ and precipitation $(\mathrm{mm})$ month means in Rio de Janeiro City during the period between 1961 and 1990 (climatological normal) (A) and also during 2009 (B). Data collected from reference 7.

*e-mail: alicesato@unirio.br 


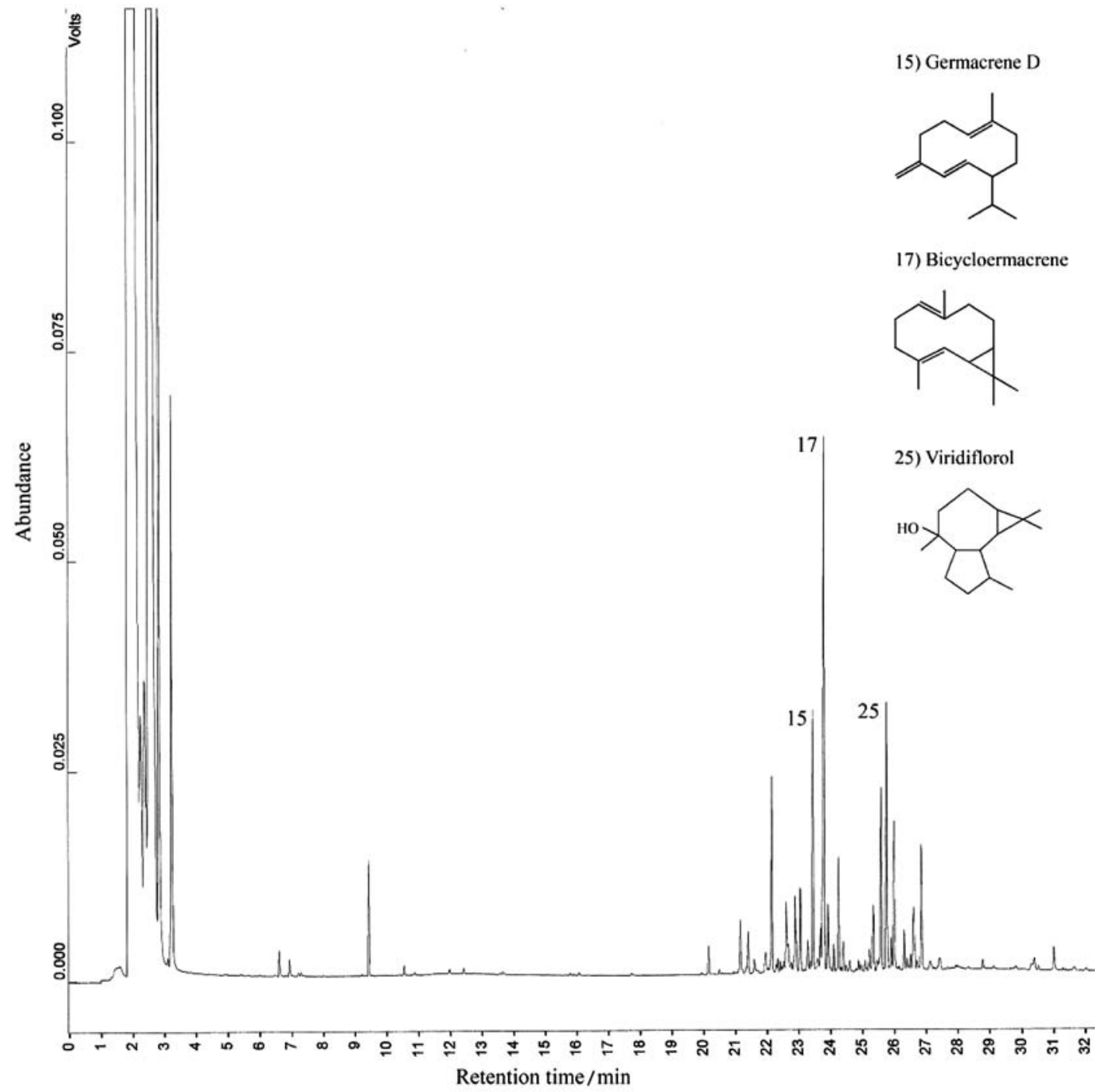

Figure S2. GC-FID of the essential oil obtained from Eugenia neonitida fresh leaves collected in February 2009 and the chemical structure of its major compounds. 


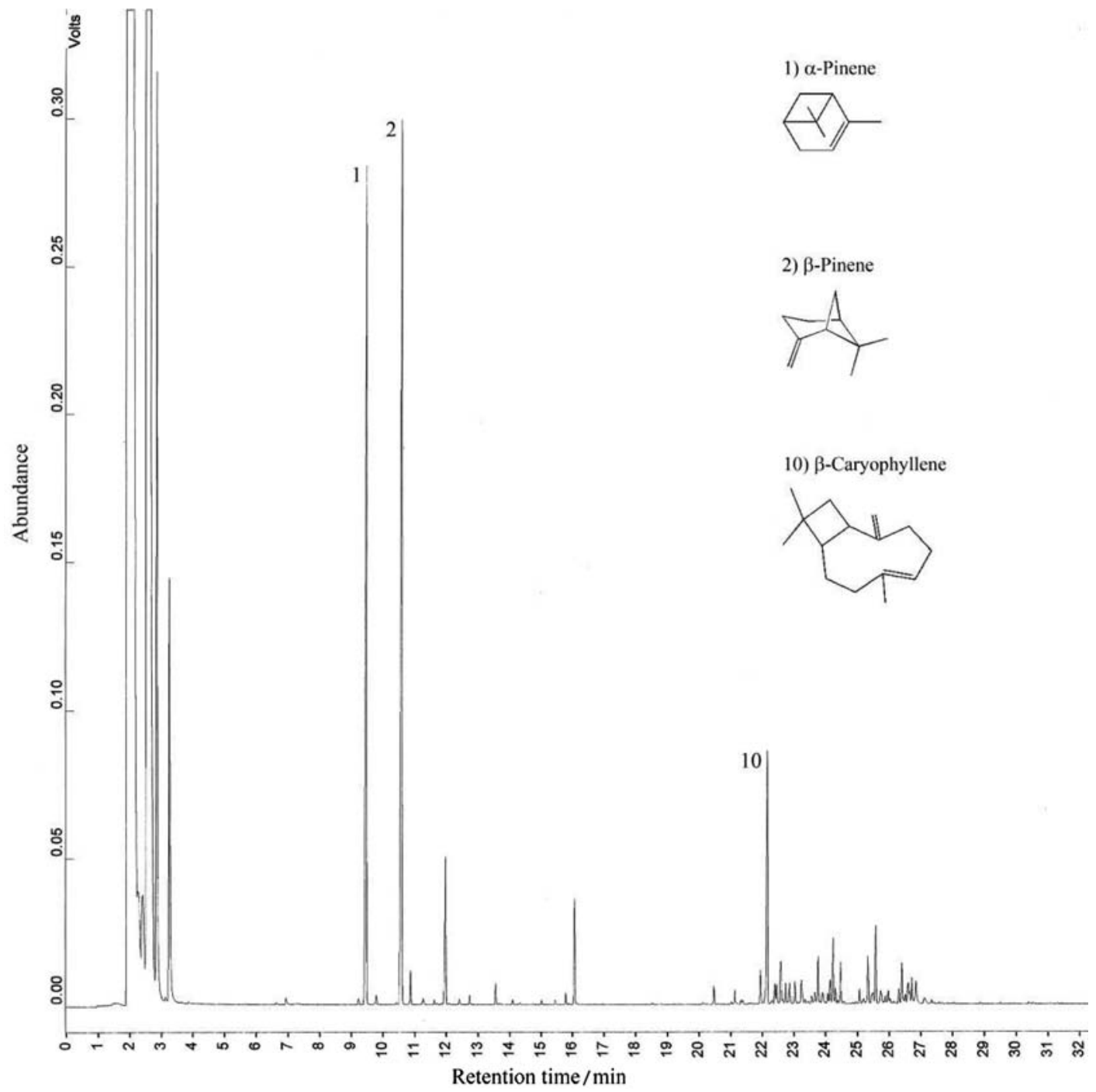

Figure S3. GC-FID of the essential oil obtained from Eugenia rotundifolia fresh leaves collected in February 2009 and the chemical structure of its major compounds. 

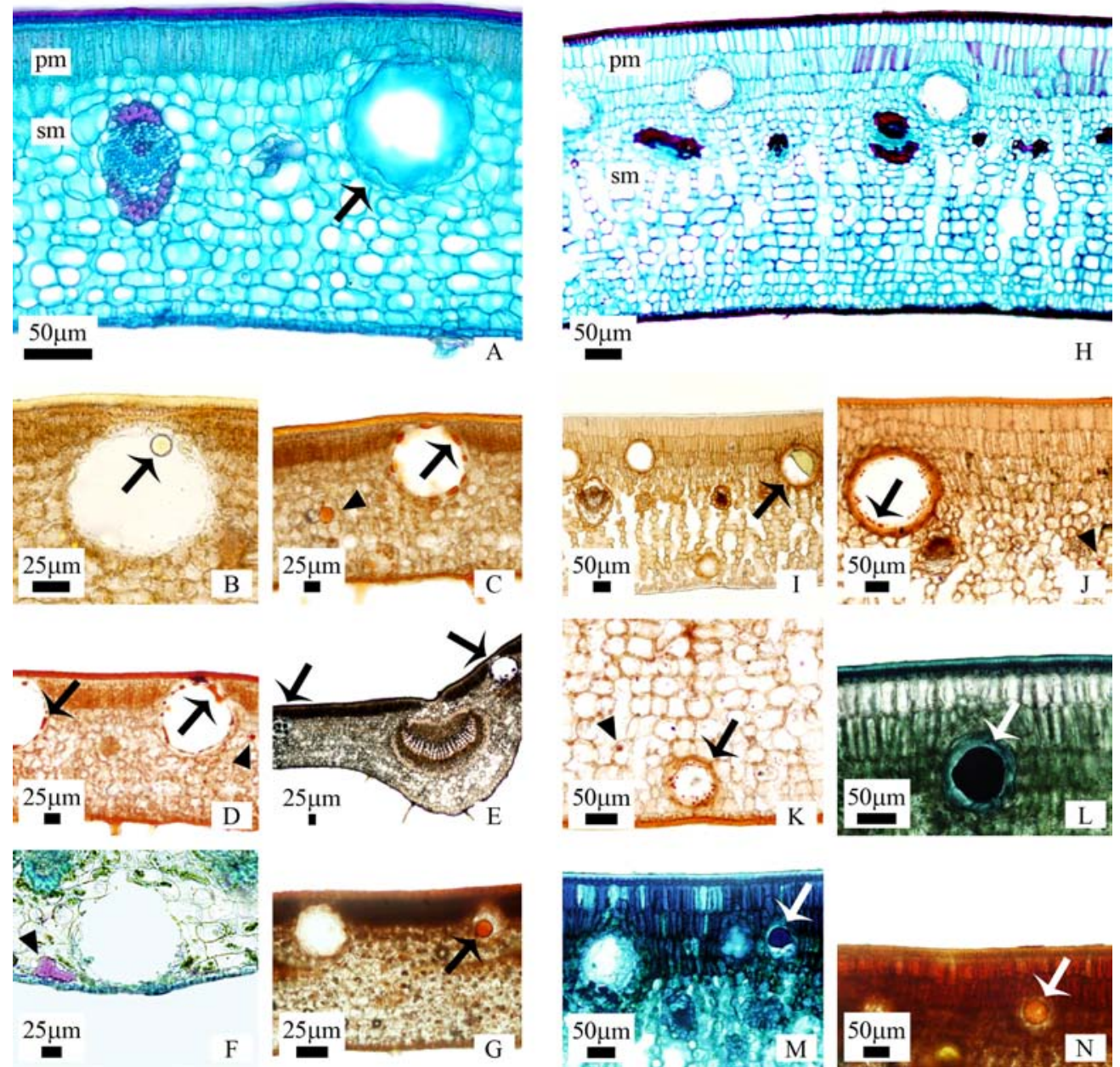

Figure S4. Transversal hand sections in Eugenia neonitida (A-G) and Eugenia rotundifolia (H-N) fresh leaves and its histochemistry, highlighting the response of secretory cavities (arrows) and parenchyma cells (arrowheads) to histochemical tests. A and $\mathrm{H}$ : transversal hand sections profiles stained with alcian blue and fucsin, showing the secretory cavities (arrows) overall distribution. B and I: arrows show the essential oil droplets in its natural color inside secretory cavities. C and J: lipids orange stained with Sudan III. D and K: lipids orange stained with Sudan IV. E and L: lipids dark stained with Sudan black B. F and M: pink neutral and blue acid lipids stained with Nile blue sulphate. G and N: rubber orange stained with Oil Red O. Legend: pm = palisade mesophyll, sm = spongy mesophyll, arrows = secretory cavities content, arrowheads = parenchyma cells content. 